ROCZNIKI FILOZOFICZNE

Tom LXVIII, numer $4-2020$

DOI: https://doi.org/10.18290/rf20684-5

GRZEGORZ BUGAJAK

\title{
CZY PROCESY NATURALNE MOGĄ REALIZOWAĆ CELE NADNATURALNE?
}

\section{WSTĘP}

Mogłoby się wydawać, że dzisiaj, ponad 150 lat po sformułowaniu teorii ewolucji w wersji zaprezentowanej przez Karola Darwina, wszystkie możliwe stanowiska $\mathrm{w}$ debacie ewolucjonizm-kreacjonizm zostały dawno sformułowane i przedyskutowane. Jednak z jakiegoś powodu debata nad tym problemem ciągle odżywa. W szczególności, wielu autorów deklarujących swoje przywiązanie do myśli chrześcijańskiej jest niezadowolonych z nadmiernych, ich zdaniem, ustępstw, jakie inni przedstawiciele tej tradycji czynią wobec ewolucjonizmu. Wychodząc z przesłanek czy to teologicznych o wyższości poznania kierowanego światłem Objawienia nad poznaniem naturalnym, czy też filozoficznych - np. o realnym istnieniu gatunków naturalnych, kwestionują - o ile nie idee ewolucyjne w całości (co współcześnie byłoby niezwykle trudne do przeprowadzenia, choć zdarza się w niektórych kręgach religijnych) - to przynajmniej niektóre elementy ewolucyjnego obrazu świata. W ten nurt protestu wobec zbyt daleko idących „uzurpacji” ewolucjonizmu wpisał się kilkanaście lat temu kardynał Christoph Schönborn swoją znaną wypowiedzią: „Idea ewolucji, jeśli ją rozumieć jako pochodzenie od wspólnego przodka, może być prawdziwa, lecz rozumiana $\mathrm{w}$ sensie neodarwinowskim jako niekierowany i nieplanowany proces powstawania przypadkowych zmian i naturalnej selekcji nie może być prawdziwa"1. Kłopot z tym stanowiskiem, podzielanym przez wielu chrześcijan, polega na tym, że co raz lepiej rozpoznawany w nauce proces

Dr hab. GRZEGORZ BUGAJAK, prof. UKSW — dyrektor Instytutu Filozofii Uniwersytetu Kardynała Stefana Wyszyńskiego w Warszawie.

${ }^{1}$ Cyt. według tłumaczenia polskiego: Christoph SchÖNBORN, „Odnajdywanie zamysłu w przyrodzie”, tłum. Piotr Lenartowicz, Filozoficzne Aspekty Genezy 2, nr 3 (2005-2006): 19. 
ewolucji ma właśnie taki charakter: nie sposób dostrzec w nim jakiegokolwiek planu, a czynnikiem decydującym o jego przebiegu jest przypadek.

Napięcie między poglądami religijnymi a ewolucyjnym obrazem przyrody niepokoiło już samego Darwina, gdy w jednym ze swoich listów pisał: „Nie mogę traktować wszechświata jako wyniku działań ślepego przypadku. A jednak w szczegółach nie mogę też dostrzec żadnych dowodów dobroczynnej celowości (design) czy w ogóle jakiejkolwiek celowości"². Rozwój jego teorii poszedł jednak w kierunku, którego sam — ze względów religijnych — się obawiał. Dzisiaj ,teoria ewolucji jest co raz lepiej potwierdzana w odniesieniu do przekonania, że cudowne formy życia są rezultatem procesu ewolucyjnego, niezależnego od intencji jakiegokolwiek umysłu, i że proces ten przebiega automatycznie, bez potrzeby okolicznościowych, specjalnych dostosowań" ${ }^{\prime 3}$.

Taka wizja przyrody niepokoi wielu wierzących chrześcijan ${ }^{4}$, czego wyrazem były kontrowersje wywołane wypowiedzią św. Jana Pawła II z 1996 roku, w której papież deklarował, że ewolucja jest czymś więcej niż hipotezą. Podczas gdy jedni z zadowoleniem witali oficjalne stanowisko Kościoła, przychylne ewolucjonizmowi, inni analizowali językowe detale papieskiej wypowiedzi (jej oryginał był opublikowany w języku francuskim) dowodząc, że papież bynajmniej nie zaakceptował ewolucyjnej wizji świata. Te kontrowersje doprowadziły w 2004 r. do wydania przez Międzynarodową (papieską) Komisję Teologiczną dokumentu, dotyczącego „licznych zniekształceń znaczenia listu Jana Pawła o ewolucji z roku 1996”, w którym napisano, że „bezkierunkowy proces ewolucji - wykraczający poza granice Bożej Opatrzności - nie może po prostu zaistnieć" ". Zgadzając się z opinią, że poza Bożą Opatrznością nic istnieć nie może, trzeba jednak zapytać jak tę Opatrzność należy rozumieć. Co to na przykład znaczy, że - jak mówił papież Benedykt XVI w czasie swojej intronizacji-,każdy z nas jest

\footnotetext{
${ }^{2}$ Cyt. za: Marek SŁomKa, Działanie Boga w świecie. Analiza filozoficzna (Lublin: Wydawnictwo KUL, 2018), 217.

${ }^{3}$ Wesley J. Wildman, „Evaluating the Teleological Argument for Divine Action”, w: Evolutionary and Molecular Biology. Scientific Perspectives on Divine Action, red. Robert John Russell, William R. Stoeger, Francisco J. Ayala (Vaticano: Vatican Observatory Publications; Berkeley, CA: Center for Theology and the Natural Sciences, 1998), 118.

${ }^{4}$ A dla niewierzących staje się powodem zgryźliwych komentarzy w rodzaju, że uczony, który jednocześnie jest osobą wierzącą cierpi na coś w rodzaju syndromu Dr. Jekyll/Mr. Hyde lub na schizofrenię. Zob. Elaine H. Ecklund, Christopher P. Scheitle, „Scientists”, w: The Warfare between Science and Religion, red. Jeff Hardin, Ronald L. Numbers, Ronald A. Binzley (Baltimore: John Hopkins University Press, 2018), 290.

${ }^{5}$ SCHÖNBORN, „Odnajdywanie zamysłu w przyrodzie”, 21.
} 
wyrazem myśli Bożej. Każdy z nas stał się upragnionym, ukochanym i wręcz koniecznym"6. Jest oczywiste, że ta piękna prawda, do której odwoływał się nowo wybrany papież, a która do głosu dochodzi na licznych stronach Pisma św., jak np. w Księdze Proroka Jeremiasza: „Zanim ukształtowałem cię w łonie matki, znałem cię" (Jr 1,5), nie może oznaczać jakiegoś rodzaju fizycznej konieczności. Jej „mechaniczne” rozumienie nie tylko byłoby trudne do utrzymania w świetle wiedzy o świecie i o człowieku, jaką dziś posiadamy, ale byłoby też dramatyczną trywializacją biblijnego przesłania. Rodzi się więc potrzeba poszukiwania takich interpretacji, które uchronią fundamentalne prawdy wiary przed niebezpieczeństwem sprowadzania ich do detalicznego „przepisu na świat”, a przy okazji nie będą sytuowały chrześcijan w gronie wrogów nauki.

Takie poszukiwanie jest zasadniczym celem niniejszego artykułu. Cel szczegółowy zaś został sformułowany w postaci tytułowego pytania: Czy procesy naturalne mogą realizować cele nadnaturalne? "Cele nadnaturalne” odnoszą się tutaj do takich celów, które można przypisać stwórczej aktywności Boga, zaś „procesy naturalne” — do współczesnej wiedzy przyrodniczej, zwłaszcza ewolucyjnej, dotyczącej sposobu funkcjonowania świata przyrody. Odpowiedź na to pytanie domaga się najpierw refleksji nad klasycznym zagadnieniem celowości w świecie stworzonym (p. 2). Ponieważ z niektórymi koncepcjami takiej celowości związany jest pogląd, że Bóg ingeruje w specjalny sposób w świat przyrody — czy to „z konieczności” w kluczowych momentach jego historii („konieczność” oznacza tutaj sytuację, w której jakiś skutek, który zdaje się być pożądany przez Boga, i który faktycznie zaszed — np. powstanie życia, pojawienie się człowieka — nie zdarzyłby się bez specjalnej interwencji Bożej), czy też ,z własnej woli” w odniesieniu do zdarzeń partykularnych (,z własnej woli”, czyli w przeciwieństwie do wyżej wspomnianej „konieczności” — chodzi o takie zdarzenia, które z punktu widzenia „planów Bożych” w odniesieniu do świata zajść nie musiały, jak np. cuda uzdrowień) - kolejnym przedmiotem analizy będzie problem działania Boga w świecie (p. 3), a także tzw. zasada domknięcia przyczynowego, która zdaje się wykluczać możliwość takich ingerencji (p. 4). Ostatnia część artykułu (p. 5) jest próbą wskazania na panenteizm jako na koncepcję, która jest z gruntu zgodna z chrześcijaństwem, a która umożliwia ujęcie w spójnym obrazie naukowej wiedzy o rozwoju przyrody z religijnym przekonaniem o miejscu i działaniu Boga w stworzonym świecie.

\footnotetext{
${ }^{6}$ Tamże.
} 


\section{BÓG I CELOWOŚĆ W ŚWIECIE}

Dość powszechnie uważa się, że odrzucenie celu jako kategorii wyjaśniającej funkcjonowanie świata przyrody dokonało się w nowożytności, wraz z powstaniem nauk przyrodniczych. Skuteczne poszukiwanie przyczyn, rozumiane przede wszystkim jako ustalanie zjawiskowych antecedensów innych zjawisk, stało się siłą napędową rodzącej się nauki, która jednocześnie odrzuciła wyjaśnianie w kategoriach celu jako bezpłodne ${ }^{7}$. Jednakże we współczesnej refleksji filozoficznej można odnaleźć rozmaite próby obrony tej kategorii. Zauważa się na przykład, że źródłem wielu nieporozumień, prowadzących do zbyt szybkiego pozbycia się terminu „cel” ze słownika filozoficznego, jest pomieszanie tzw. teleologii naturalnej ze świadomymi celami działania ${ }^{8}$. Jedni przy tym ograniczają myślenie o zjawiskach mających charakter celowy do takich, którym da się przypisać świadomy podmiot, jak np. reprezentacje mentalne, intencje, cele - w sensie: powody (purpose), znaczenia i wartości ${ }^{9}$ a inni - niejako odwrotnie - chcąc ocalić kategorię celu w rozważaniach filozoficznych o naturze, wskazują na niepsychiczne rozumienie celu jako „kres procesu, optymalny stan układu lub jego normalne funkcjonowanie" ${ }^{\text {, }}$, niekiedy ostrożnie mówiąc w tym kontekście o quasi-celowości ${ }^{11}$.

W przypadku celowości ograniczanej do działań świadomego agenta, jaka jest $\mathrm{z}$ definicji wykluczona w przypadku procesów naturalnych, pewna próba jej - mimo wszystko - odnalezienia w tych procesach idzie po linii przykładów takich działań świadomych podmiotów, które osiągają swoje cele bez wyraźnej intencji: „zdolny rzemieślnik wykonuje swoje zadanie szybko i skutecznie, przy minimalnym zaangażowaniu świadomego myślenia, a często - w ogóle bez konieczności myślenia o tym, co robi”"12. Podobnie w przypadku uczenia się jazdy na rowerze: „ciało samo wie, jak rozkładać swoją wagę tak, by rower nie upadł; w ten sposób celowy skutek

\footnotetext{
${ }^{7}$ Zob. np. Kamil MAJCHEREK, „Ockhamowa krytyka teleologii a narodziny nowożytnego rozumienia celowości świata natury”, Studia Philosophiae Christianae 53, nr 4 (2017): 52-59.

${ }^{8}$ Zob. Zbigniew WróBlEwSKI, „O pewnej próbie obrony wyjaśniania teleologicznego”, Roczniki Filozoficzne 60, nr 4 (2012): 344-345.

${ }^{9}$ Zob. Jeremy Sherman, Terrence W. Deacon, „Teleology for the Perplexed: How Matter Began to Matter", Zygon 42, nr 4 (2007): 874.

${ }^{10}$ WRÓBLEWSKI, „O pewnej próbie”, 343.

${ }^{11}$ Zob. Wiesław DYK, „Celowość przyrody w świetle zasad antropicznych”, Studia Gdańskie 14 (2001): 135-136.

${ }^{12}$ John F. Owens, „Creation and End-Directedness”, Sophia 49, nr 4 (2010): 496.
} 
jest osiągnięty bez potrzeby istnienia świadomego zamiaru" ${ }^{13}$. Intencją tego rodzaju przykładów jest wykazanie, że można mówić o celu jakiegoś procesu nawet wówczas, gdy nie istnieje podmiot (lub takiego podmiotu nie da się bezpośrednio wskazać), który by się nad przebiegiem takiego procesu zastanawiał. Intencją dalszą, zwłaszcza jeśli piszą o tym autorzy chrześcijańscy, może być sugestia, że w podobny sposób można pojąć celową aktywność Boga w przyrodzie, wszędzie tam, gdzie pewne cele są osiągnięte (np. zapewnienie przeżycia danej jednostce lub jej potomstwu), choć nie widać kogoś, kto świadomie prowadzi do osiągnięcia takiego celu. W tym przypadku jednak mamy do czynienia po prostu ze wskazaniem na pewne automatyzmy $\mathrm{w}$ zachowaniu skądinąd świadomych podmiotów, a nie na przekonujące przypadki świadomego i celowego, choć jakoś ukrytego działania. Dlatego tego rodzaju obrona celowego działania Boga jest nieprzekonująca.

W drugim przypadku - celowości ujawniającej się w procesach naturalnych — niektóre dokładniejsze jej określenia wskazują na próby użycia nieco innego języka na opisanie tego, co zwykło się dziś ujmować zgodnie $\mathrm{z}$ generalną tendencją nowożytną - w języku przyczynowości i determinizmu. Bardzo wyraźnie widać to $\mathrm{np}$. w sformułowaniu jednego $\mathrm{z}$ bardziej znanych polskich filozofów przyrody XX wieku orientacji chrześcijańskiej Tadeusza Wojciechowskiego: „Przez celowość rozumiemy taki przebieg procesów, w którym osiągają one stan końcowy, jaki był określony przez stan poczatkowy" (podkr. G. B.) ${ }^{14}$. W odniesieniu do szczególnie dyskutowanych w tym kontekście procesów ewolucyjnych, inny filozof tej orientacji, Kazimierz Kloskowski, podkreślając że nie można mówić o celowym ukierunkowaniu tych procesów, pisał: „Cel bowiem «mieści się» w początkowym stanie obiektów podlegających ewolucji, bądź w zachowawczej aktywności tychże obiektów. I tylko w tej płaszczyźnie uzasadnione jest odwoływanie się do determinizmu celowościowego"15. Termin „determinizm celowościowy" wydaje się tu tylko ozdobnikiem, być może służącym próbie werbalnego uratowania celowości w opisie procesów ewolucyjnych, lecz treściowo równoważnym ze zwykłym determinizmem.

\footnotetext{
${ }^{13}$ Tamże. Autor podaje ten przykład za: Anthony Kenny, The metaphysics of mind (Oxford: OUP, 1992), 36.

${ }^{14}$ Tadeusz WoJciechowski, Zarys filozofii przyrody ożywionej (bmw: Wydział Teologiczny Uniwersytetu Opolskiego, 1997), 84.

${ }^{15}$ Kazimierz KLoskowski, „Cel i wyjaśnianie celowościowe ewolucji”, Studia Gdańskie 9 (1993): 261.
} 
O autentycznej celowości w świecie przyrody można mówić jedynie w kategoriach celów wewnętrznych i nieświadomych. Na przykład dążenie do utrzymania życia i reprodukcji jest przejawem wewnętrznej celowości organizmów, których czynności nie mogą być ani dowolne ani przypadkowe, jeśli mają służyć osiągnięciu takiego celu ${ }^{16}$. Dla uniknięcia nieporozumień związanych z przypisywaniem celowości światu istot żywych trzeba przy tym pamiętać o kilku jej ważnych cechach: 1) Tak rozumiana celowość dotyczy całego organizmu, a nie jego pojedynczych funkcji czy organów - jak np. oka, gdzie jest po prostu elementem definicji: oko nie byłoby okiem, gdyby nie widziało; jest nim, bo jego celem jest widzenie ${ }^{17}$. 2) Cel nie jest czymś dodatkowym, nadanym z zewnątrz, lecz utożsamia się z samym życiem $^{18} \mathrm{i}$ istnieniem ${ }^{19}$. 3) Jest to tym samym „cel nieświadomy” (purposiveness without a purpose), albo wewnętrzny (inner teleology) ${ }^{20}$. W takiej perspektywie jednak Bóg staje się niewidoczny. W szczególności, nie ma dziś powrotu do optymizmu św. Tomasza, który w swojej quinta via utrzymywał, że ponieważ w świecie istnieją byty nieświadome, które jednak działają tak, by „dopiąć tego, co dla nich najlepsze”, to w takim ich działaniu ujawnia się ktoś myślący, kto prowadzi te byty ku ich celowi ${ }^{21}$. Jednak w myśli Akwi-

${ }^{16}$ Zob. WoJCIECHOWSKI, Zarys filozofii przyrody ożywionej, 91.

${ }^{17}$ Zob. John F. Owens, „Creation and End-Directedness”, 493-494. Autor przypisuje ten przykład Arystotelesowi.

${ }^{18}$ Zob. WoJCIECHOWSKI, Zarys filozofii przyrody ożywionej, 91.

${ }^{19}$ Zob. Owens, „Creation and End-Directedness”, 494: „Their very existence consists in a striving for goals, so that it is not possible to think of them as existing at all, unless they are performing the peculiar striving that is «living». For a chicken to exist is precisely for it to be pursuing the goods of a chicken, foraging, laying, reproducing. A chicken that has lost this end-directedness is no longer even a chicken and has lost what counts as actual existence for a living thing”.

${ }^{20}$ Zob. William P. Kiblinger, „Evolution and subjectivity”, Zygon 42, nr 1 (2007), 194.

${ }^{21}$ „Piątą drogę wskazuje fakt kierownictwa wszystkim rzeczami na świecie. Widzimy bowiem, jak rzeczy pozbawione [wszelkiego] poznania, mianowicie ciała naturalne, działają celowo. Objawia się to w tym, że zawsze lub bardzo często działają jednakowo, a działają po to, by dopiąć tego, co dla nich najlepsze. Jasne więc, że nie dochodzą do celu mocą przypadku, ale w sposób zamierzony. Otóż rzeczy pozbawione [wszelkiego] poznania o tyle dążą do celu, o ile są skierowane ku niemu przez kogoś obdarzonego zdolnością poznania i myślenia, tak jak strzała przez łucznika. A więc istnieje ktoś myślący, kto kieruje wszystkimi naturalnymi rzeczami ku celowi - i jego to zwiemy Bogiem" - św. Tomasz, Suma teologiczna, t. 1, O Bogu, cz. 1, zagadnienie 2, artykuł 3, tłum. Pius Bełch i in. (London: Veritas, 1975), 49; cyt. za: Mirosław TwarDowski, „«Quintavia» św. Tomasza z Akwinu we współczesnej dyskusji filozoficzno-przyrodniczej”, Studia Sandomierskie 24 (2017): 262. We współczesnym i bardziej ogólnym sformułowaniu: „Argument $\mathrm{z}$ celowości jest argumentem wychodzącym z ładu lub prawidłowości w świecie i prowadzącym do Boga czy, wyrażając się dokładniej — do potężnego, wolnego, bezcielesnego i racjonalnego sprawcy, który za ten ład jest odpowiedzialny” — Richard G. SwINBURNe, „Argument z celowości”, tłum. Ryszard Mordarski, Analiza i Egzystencja 18 (2012): 60. 
naty odnajdujemy też inne, bardziej subtelne pojęcie celu bytów naturalnych. Celu nie w „technicznym” sensie wyznaczonego przez Boga kresu jakiegoś procesu, czy „zadania do osiągnięcia”, lecz w sensie źródła wszystkich rzeczy, które od Niego biorą swój początek, Jego pragną (przez swoją naturę - bo ona pochodzi od Boga) i do Niego ostatecznie wracają. Świat jest ukierunkowany celowościowo nie tylko przez Boga, ale przede wszystkim $n a$ Boga $^{22}$. Przy tym zewnętrzne rozumienie tego ukierunkowania (przez Boga) jest dziś trudne do utrzymania. Rozumienie wewnętrzne (natura świata ukierunkowana $n a$ Boga) jest zaś dostępne wyłącznie w refleksji teologicznej, która odkrywa pełne znaczenie znanej wypowiedzi Jezusa: „Wszyscy bowiem dla Niego żyją” (Łk 20,38) ${ }^{23}$.

\section{DZIAŁANIE BOGA W ŚWIECIE}

Pewną współczesną formą rozważań nad Boską celowością w świecie przyrody są analizy działania Boga w świecie (divine action). Problematyka ta cieszy się w ostatnich dziesięcioleciach sporą uwagą, przede wszystkim wśród uprawiających refleksję w kręgu zagadnień „,nauka i religia/teologia"24. W naukowym obrazie świata poszukuje się możliwości, a niekiedy

\footnotetext{
${ }^{22}$ Por. Kamil Majcherek, „Tomasz z Akwinu i William Ockham o celowości świata natury”, Rocznik Tomistyczny 5 (2016): 278.

${ }^{23}$ Zdanie to jest zwieńczeniem odpowiedzi, jakiej Jezus udziela saduceuszom w dyskusji o zmartwychwstaniu. Taki temat owej dyskusji wskazywałby, że w cytowanym zdaniu akcent pada na to, że wszyscy żyją. Można jednak zaproponować rozszerzającą interpretację tego fragmentu Ewangelii. Dyskusja zaczyna się od pytania o to kto po zmartwychwstaniu będzie mężem kobiety, która za życia miała ich siedmiu, na co pada odpowiedź: „Dzieci tego świata żenią się i za mąż wychodzą. Lecz ci, którzy uznani zostaną za godnych udziału w świecie przyszłym i w powstaniu z martwych, ani się żenić nie będą, ani za mąż wychodzić" (Łk 20,34-35). Małżeński kontekst tej wypowiedzi jest rzeczą wtórną w tym sensie, że staje się dla Jezusa pretekstem do pouczenia o dużo szerszej wymowie. „Dzieci tego świata” angażują się w rozmaite działania i relacje, które z punktu widzenia „świata przyszłego" nie mają znaczenia, ponieważ jedyne, co się liczy, to fakt, że „wszyscy żyją dla Niego”. Przy czym opozycja „ten świat” — „świat przyszły” nie musi mieć charakteru czasowego (gdzie przejściem między tymi światami jest indywidualna śmierć fizyczna, albo czasowo rozumiany koniec świata), lecz duchowy (jak w opozycji odnajdywanej w wielu innych miejscach Ewangelii: „dzieci tego świata” — „dzieci Królestwa").

${ }^{24}$ Por. Gijsbert van den BRINK, „In defence of dialogue - Yves Gingras, Science and Religion: An Impossible Dialogue" (recenzja), Metascience 28 (2019): 226. Zob. też Jeffrey KoPerSKI, Divine Action, Determinism, and the Laws of Nature (London-New York: Routlege, 2020), 121 i Wesley J. Wildman, „The Divine Action Project, 1988-2003”, Theology and Science 2, nr 1 (2004): 31-75.
} 
nawet dowodów ${ }^{25}$ Bożej interwencji w bieg natury. Popularnym, choć czasami kwestionowanym rozróżnieniem jest to na „szczególne interwencje” - Special Divine Action (SDA) i „działanie ogólne” — General Divine Action (GDA). SDA to przekonanie, że Bóg działa niekiedy - w wybranych czasach i miejscach. Działanie to realizuje się np. przez tradycyjnie rozumiane cuda, może być odpowiedzią na modlitwy błagalne, jest jakąś formą osobistej interwencji Boga w bieg zdarzeń i sposobem wyrażania się Jego szczególnej opatrzności. Natomiast przez GDA rozumie się takie działanie Boga, które dotyczy całego stworzenia bez wyjątku i ,jednocześnie” (tzn. nie wyróżnia żadnych czasów ani miejsc). Jest więc sposobem wyrażenia takich idei, jak creatio continua, czy przekonania o tym, że Bóg utrzymuje porządek w świecie za pomocą ustanowionych przez siebie (i odkrywanych w nauce) praw przyrody ${ }^{26}$.

Według niektórych autorów, chrześcijańskie rozumienie Boga nie może zadowolić się Jego działaniem „ogólnym” (GDA), nie może zaakceptować przekonania, że Bóg nie przeprowadza szczególnych działań, które wpływają na bieg zdarzeń w świecie ${ }^{27}$. Jak mocno pisze jeden z nich: „Jaki pożytek byłby z Boga, który nie mógłby realnie zmienić biegu historii czy przyrody?"28 a inny dodaje: „nie byłoby wierzących chrześcijan, gdyby nie wiara w Boga-Który-Działa" ${ }^{29}$. Możliwość takiego szczególnego działania miałaby być zapewniona przez to, że prawa przyrody nie wyznaczają jednoznacznie tego, co dzieje się w świecie ${ }^{30}$, że przyroda jest „przyczynowo otwarta”, to znaczy umożliwia zachodzenie zjawisk, których przyczyny leżą poza jej naturalnym biegiem. Dla uzasadnienia tego poglądu wskazuje się najczęściej na przypadkowość zjawisk, opisywanych w teoriach kwantowych ${ }^{31}$; kwantowa niejednoznaczność miałaby zapewniać możliwość podejmowania przez Boga decyzji o tym jaki przebieg procesu, jaki stan układu, spośród wszystkich probabilistycznie przewidzianych przez teorię, faktycznie się zrealizuje.

\footnotetext{
${ }^{25}$ Poszukiwanie takich „dowodów” nie cieszy się zwykle przychylnością uprawiających refleksję w dziedzinie Science \& Religion, jest natomiast domeną zwolenników tzw. teorii inteligentnego projektu. Teoria ta nie jest jednak przedmiotem refleksji proponowanych w tym artykule.

${ }^{26}$ Por. Nicholas SAUnders, Divine Action and Modern Science (Cambridge: CUP, 2002), 21.

${ }^{27}$ Zob. Brenda de Wet, „Particular Divine Action: A Challenge to Intellectual Integrity in a Post-Christian Age”, South African Journal of Philosophy 27, nr 2 (2008): 98.

${ }^{28}$ Dennis Bielfeldt, „Can Western Monotheism Avoid Substance Dualism?”, Zygon 36, nr 1 (2001): 155 .

${ }^{29}$ De Wet, „Particular Divine Action”, 95.

${ }^{30}$ Zob. np. Robert E. UlanowicZ, „A World of Contingencies”, Zygon 48, nr 1 (2013): 87.

${ }^{31}$ Zob. np. Alvin Plantinga, „Divine Action in the World (Synopsis)”, Ratio 19, nr 4 (2006): 501-504.
} 
Kwantowy indeterminizm miałby zapewniać ponadto, że Bóg pozostaje w takim działaniu ukryty. Generalnie losowość procesów, nie tylko ta opisywana $\mathrm{w}$ teoriach kwantowych, miałaby być sposobem, w jaki Bóg realizuje swoje plany ${ }^{32}$.

Podobne próby znalezienia miejsca na szczególne Boże interwencje $\mathrm{e}^{33}$ w procesach naturalnych spotykają się jednak z wieloraką krytyką. Krytyka taka jest formułowana już od lat 60. XX wieku, zarówno przez uznanych teologów, jak Rudolf Bultmann czy Langdon Glikey, jak i — bardziej współcześnie - m.in. przez znanych w kręgach Science \& Religion filozofów Philipa Claytona i Nielsa Henrika Gregersena ${ }^{34}$. Podnosi się m.in. argument, że jedyny sposób, w jaki można zrozumieć interwencje Boga w świecie (bytu niematerialnego w świat materialny), np. cuda, to założyć, że dzieje się to z dodaniem energii, czyli ze złamaniem I zasady termodynamiki, czy ogólniej — zasady zachowania energii ${ }^{35}$. Poważniejszy zarzut dotyczy tego, że jeśli Bóg miałby wpływać na naturalny bieg przyrody, wyznaczony (nawet jeśli tylko w pewnych granicach) przez prawa natury, to dokładna analiza takich przypadków powinna wykryć „odstępstwo od normy”. Na przykład analiza statystyczna, wskazująca na naturalne prawdopodobieństwa pewnych zdarzeń, powinna wykazać, że dane zdarzenie, o którym twierdzi się, że było wynikiem interwencji Boga, nie mieści się w granicach tego, co teoretycznie

\footnotetext{
${ }^{32}$ Podnosi się argument, że skoro ludzie posługują się losowością, by osiągnąć pewne cele (grając choćby w gry losowe), to i Bóg może działać podobnie. Na przykład, jeśli celem Boga jest ,zapełnienie stworzenia życiem”, to taki cel realizuje np. osmoza w komórce, która polega na losowym ruchu cząstek. Zob. James Bradley, „Losowość i natura Boga”, tłum. Ewa Czyżowicz $\mathrm{i}$ in., Filozoficzne Aspekty Genezy 11 (2014): 226-229.

${ }^{33}$ Warto odnotować, że interwencje te można w różny sposób klasyfikować. Piotr Bylica wymienia np. trzy takie klasy: przyczynową, teologiczną i epistemiczną. Zob. Piotr ByLICA, „Naturalistic Theism on Special Divine Action within the Framework of the Model of the Levels of Analysis", Studia Philosophiae Christianae 53, nr 1 (2017): 22-23. Z punktu widzenia niniejszego artykułu tak detaliczna analiza poglądów interwencjonistycznych nie jest jednak konieczna.

${ }^{34}$ Cytaty z kilku takich „standardowych” tekstów, odrzucających interwencjonistyczną koncepcję działania Boga w świecie, można znaleźć w: Alvin Plantinga, „Divine Action”, 496-498. Początki takiej krytyki wskazuje się także w pracach wcześniejszych. Marek Słomka cytuje pewnego szkockiego duchownego, który pod koniec XIX w. pisał: „Wierzę w immanencję Boga w świecie, a nie wierzę, że pojawia się On tutaj dopiero w sytuacjach krytycznych" - SŁomKA, Działanie Boga $w$ świecie, 218.

${ }^{35}$ Zob. np. Robert LARMER, ,Divine Intervention and the Conservation of Energy: A Reply to Evan Fales”, International Journal for Philosophy of Religion 75, nr 1 (2014): 27; William R. Stoeger, „Describing God's Action in the World in Light of Scientific Knowledge of Reality”, w: Chaos and Complexity: Scientific Perspectives on Divine Action, red. Robert J. Russell, Nancey Murphy, Arthur Peacocke (Vaticano: Vatican Observatory Publications; Berkeley, CA: Center for Theology and the Natural Sciences, 1995), 244.
} 
prawdopodobne ${ }^{36}$. Wreszcie, „przyczynowa otwartość” przyrody nie jest bezdyskusyjnym faktem, lecz jest ekstrapolacją lub daleko idąca interpretacją takich teorii, jak wspominana fizyka kwantowa, czy teoria chaosu ${ }^{37}$.

Alternatywną propozycją jest uznanie, że działanie Boga w świecie może mieć jedynie charakter nieinterwencjonistyczny. Oznacza to, że „Bóg konsekwentnie respektuje porządek wynikający z praw przyrody i nigdy tego porządku nie narusza ani nie zawiesza" ${ }^{38}$, a Jego zewnętrzna ingerencja w bieg przyrody jest nie tyle niemożliwa (twierdzenie, że Bóg czegoś nie może, nawet jeżeli ta niemożliwość wpisana by była w ustanowione przez Niego prawa przyrody, zwykle budzi sprzeciw wobec „definicyjnego” przekonania o Jego wszechmocy), co nie jest potrzebna - bo Bóg jest w świecie obecny nieustannie i immanentnie. Chodzi przy tym o obecność trwałą, lecz subtelną; istnieją autorzy, którzy opowiadając się za nieinterwencjonistycznym modelem działania Boga w świecie (GDA), łączą go z przekonaniem o jakimś rodzaju ,generalnego nacisku” jaki Bóg wywiera na stworzenie, by zrealizować własne cele ${ }^{39}$. Choć, formalnie rzecz biorąc, takie stanowisko nie jest formą SDA, bo nie postuluje się tu nadzwyczajnych interwencji zachodzących w wybranych czasach i miejscach, to jednak coś w rodzaju łagodnego interwencjonizmu dochodzi tu do głosu. A wówczas zasadniczy trzon krytyki SDA dotyczy i tego, złagodzonego stanowiska, ponieważ taki „nacisk” i jego kierunek zasadniczo powinien być empirycznie wykrywalny. Dlatego trzeba zauważyć, że wypowiedzi o działaniu Boga w świecie, które można zakwalifikować jako wyraz stanowiska czystego GDA, którego nie dotyczyłaby wskazana krytyka, nie mogą mieć treści empirycznej. To powoduje, że - jak uważa wspomniany N. H. Gregersen - „przypuszczalnie nigdy nie będziemy mogli odróżnić tego, co jest boskie od tego, co naturalne

\footnotetext{
${ }^{36}$ Zob. Kazimierz JodKowski, „Kłopoty teistycznego ewolucjonizmu”, w: Kontrowersje wokót początków człowieka, red. Grzegorz Bugajak, Jacek Tomczyk (Katowice: Księgarnia św. Jacka, 2007), 214.

${ }^{37}$ Do listy naukowych koncepcji wskazujących na „otwartość przyczynową” przyrody, obok fizyki kwantowej czy innych teorii probabilistycznych i teorii chaosu deterministycznego dodaje się niekiedy także neuronauki. Zob. Kile Jones, „Falsifiability and Traction in Theories of Divine Action”, Zygon 45, nr 3 (2010): 585.

${ }^{38}$ Tadeusz PABJAN, „Nieinterwencjonistyczny model działania Boga w świecie przyrody”, Tarnowskie Studia Teologiczne 35, nr 1 (2016): 42.

${ }^{39} \mathrm{O}$ takim podejściu pisze np. Piotr ByLICA, „Naturalistic theism on General Divine Action within the Framework of the Levels of Analysis Model", Studia Philosophiae Christianae 52, nr 4 (2016): 16-18.
} 
w danym zdarzeniu"40. Na jeden z powodów takiej niemożliwości wskazuje tzw. zasada domknięcia przyczynowego.

\section{ZASADA DOMKNIĘCIA PRZYCZYNOWEGO I CUDA}

W refleksji nad badaniami naukowymi, zwłaszcza dokonywanej na tle ich relacji do teologii i do przekonań religijnych, wskazuje się często na naturalizm metodologiczny nauki. Jest to wymaganie, by w badaniach naukowych, które uważa się - mniej lub bardziej słusznie — za kierowane dyrektywą poszukiwania przyczyn zjawisk, odwoływać się wyłącznie do przyczyn i procesów naturalnych. Wymaganie to wydaje się neutralne względem przekonania o możliwości wpływania przez sferę nadnaturalną na bieg zjawisk przyrody, ponieważ - formalnie rzecz biorąc — wskazuje jedynie na ograniczenia metody naukowej. Można więc „bezpiecznie” twierdzić, że choć nauka nie może dosięgnąc sfery nadprzyrodzonej (nie w sensie zakazu, lecz w sensie kompetencji poznawczych: nie umie tego zrobić), nie może dostrzec skutków jej działania w świecie, to takiemu działaniu nie zaprzecza, wyznając jedynie swoją wobec niego bezsilność poznawczą. Istnieją jednak co najmniej dwa powody, dla których sztywne, epistemologiczne oddzielenie poznania świata natury, dokonującego się w naukach przyrodniczych od poznania świata nadprzyrodzonego, pozostającego w kompetencjach teologii nie może być ostatnim słowem w dyskusji nad wnioskami, jakie płyną z refleksji nad naukową eksploracją rzeczywistości, a zwłaszcza nad skutecznością naukowej metody.

Pierwszy z tych powodów wiąże się z sukcesami metodologicznie naturalistycznej nauki. Jeżeli taki rodzaj badania świata, w którym programowo pomija się czynniki ponadnaturalne okazuje się badaniem skutecznym, to skuteczność ta musi mówić coś o świecie, który poddaje się takiemu badaniu. Teza epistemologiczna — o właściwych metodach badania świata — implikuje tezę ontologiczną — o jego „konstrukcji”. Innymi słowy, naturalizm metodologiczny implikuje jakąś wersję naturalizmu ontologicznego ${ }^{41}$.

\footnotetext{
${ }^{40}$ Niels H. Gregersen, ,Special Divine Action and the Quilt of Laws: Why the Distinction between Special and General Divine Action Cannot Be Maintained", w: Scientific Perspectives on Divine Action: Twenty Years of Challenge and Progress, red. Robert John Russell, Nancey Murphy, William R. Stoeger (Vaticano: Vatican Observatory Publications; Berkeley, CA: Center for Theology and the Natural Sciences, 2008), 195; zob. też JoNES, „Falsifiability and Traction in Theories of Divine Action”, 583-584.

${ }^{41}$ Por. Michał Heller, „Chrześcijański naturalizm”, Roczniki Filozoficzne 51, nr 3 (2003): 45-46: „Skuteczność metod empirycznych mówi coś o rzeczywistości, a tym, co mówi, może być m.in. wniosek o słuszności jakiejś wersji monizmu ontologicznego"; Kazimierz JoDKowsKI,
} 
Powód drugi wiąże się z tzw. zasadą domknięcia przyczynowego. Jeśli możemy racjonalnie zakładać, że poszukiwanie naturalnych przyczyn zdarzeń jest strategią prowadzącą do wiarygodnego wyjaśnienia sposobu funkcjonowania świata, to tylko wtedy, gdy uznamy także, że na bieg zdarzeń mają wpływ tylko czynniki naturalne - takie, jakie jest w stanie odkryć i faktycznie odkrywa nauka. Choć formalnie rzecz biorąc zasada domknięcia przyczynowego jest czymś innym niż naturalizm metodologiczny, to jednak — jak niektórzy słusznie twierdzą — jest ona elementem tej formy naturalizmu, rozumianej konsekwentnie.

Zasada domknięcia przyczynowego nie wynika z żadnych konkretnych odkryć naukowych ${ }^{42}$, jest jednak podstawą, nadającą wszelkim poszukiwaniom naukowym sensowność. $Z$ tego powodu trzeba ją traktować poważnie, nawet jeśli prowadzi ona do wykluczenia możliwości nadzwyczajnych interwencji Boga, w tym cudów. Taką konsekwencję wspomnianej zasady dostrzega np. jeden z bardziej znanych przedstawicieli dziedziny „nauka a religia” Alvin Plantinga, gdy pisze, że nauka zaprzeczałaby cudom, gdyby świat był systemem zamkniętym ( $w$ takim sensie, w jakim np. w termodynamice mówi się o układach izolowanych) i przyczynowo domkniętym (causally closed); tymczasem nie ma sposobu naukowego udowodnienia żadnej z tych rzeczy ${ }^{43}$. W tym ostatnim Plantinga ma rację, co pozwala mu ostatecznie odrzucić zasadę domknięcia przyczynowego (the principle of causal closure). Jednakże odrzucenie to ma wyłącznie walor filozoficznego wyboru, motywowanego chęcią utrzymania tradycyjnego rozumienia cudów. Teologia zna jednak, nie od dzis ${ }^{44}$, subtelniejsze sposoby rozumienia zdarzeń cudownych niż przypisywanie Bogu bezpośrednich, fizycznych ingerencji w naturalny bieg świata. Współczesne analizy cudów wskazują na ich wymiar egzystencjalny i duchowy, podkreślając, że fizyczny aspekt takich zdarzeń ma znaczenie drugorzędne, że rozstrzygnięcie o zewnętrznej cudowności zdarzenia nie jest konieczne, a nawet nie jest zasadniczo możliwe ${ }^{45}$. Czyjaś duchowa

„Twarde jądro ewolucjonizmu”, Roczniki Filozoficzne 51, nr 3 (2003): 82: „Teza naturalizmu metodologicznego ma sens przy pewnych mocnych założeniach ontologicznych — kiedy albo Boga nie ma, albo jeśli jest, to nie działa w bezpośredni sposób”.

${ }^{42}$ Por. Ralf B. Bergmann, „Does Divine Intervention Violate Laws of Nature?”, Organon F 26, nr 1 (2019): 88.

${ }^{43}$ Zob. Plantinga, ,Divine Action”, 498-501.

${ }^{44}$ Jednym z najbardziej znanych teologów, którzy przyjmują zasadę domknięcia przyczynowego i odrzucają klasycznie rozumiane cuda był Rudolf Bultmann (1884-1976). Zob. BERGMANN, „Does Divine Intervention Violate Laws of Nature?”, 87-88.

${ }^{45}$ Zob. np. Adam ŚwIEŻYŃSki, Filozofia cudu. W poszukiwaniu adekwatnej koncepcji zdarzenia cudownego (Warszawa: Wydawnictwo UKSW, 2012), 100-111. 
przemiana, odkrycie prawdy, która może przemienić całe życie człowieka, mogą zostać wywołane przez czynniki zewnętrznie zwyczajne: wschód słońca nad morzem może wyzwolić taką przemianę wewnętrzną, jakiej nie musi przysłużyć się nawet niewytłumaczalne ustąpienie potencjalnie śmiertelnej choroby. Co więcej, można powiedzieć, że zdarzenie jest tym bardziej cudowne, im większa jest dysproporcja między jego zewnętrznymi okolicznościami a duchowym pożytkiem, jaki odnosi świadek albo „przedmiot” takiego zdarzenia.

Również wiele cudów ewangelicznych można zinterpretować zgodnie z zasadą domknięcia przyczynowego. Tym co uderza w opisanych w Ewangelii cudach uzdrowień jest okoliczność, że żaden z nich nie polegał na fizycznym odwróceniu procesów naturalnych, czy innych domniemanych zdarzeń: chromy, owszem, odzyskał władzę w nogach, lecz nikt nie odzyskał nóg, których byłby pozbawiony na przykład na skutek nieszczęśliwego wypadku. Niewidomi odzyskiwali zdolność widzenia, lecz nie oczy. Co ciekawe, zarówno tradycyjna filozofia, jak i współczesna wiedza medyczna pozwala zrozumieć te zdarzenia w sposób, który nie odwołuje się do fizycznej ingerencji w świat. Filozoficzna teza o jedności psychofizycznej człowieka traktuje go jako byt cechujący się fundamentalną jednością, w którym „elementy” duchowy i cielesny są możliwe do wyróżnienia w intelektualnej analizie, lecz nie istnieją niezależnie od siebie. Z kolei w medycynie mamy dzisiaj, z jednej strony, zjawisko placebo, gdzie poprawa stanu fizycznego pacjenta jest osiągana wyłącznie na skutek jego przekonania, że jest leczony, a z drugiej-rozpoznanie psychosomatycznego charakteru wielu chorób, gdzie fizyczny stan chorobowy jest spowodowany nastawieniem psychicznym chorego. Można więc sądzić, że to, co było cudownego w uzdrowieńczych interwencjach Jezusa i Apostołów, to wpływ, jaki mieli oni na psychiczny i duchowy stan uzdrawianych osób, a niekoniecznie bezpośrednio na ich cielesność.

Do innej kategorii zdarzeń cudownych, wymagających, jak się niekiedy sądzi, bezpośrednich ingerencji Boga należą te, które były decydujące w rozwoju życia i pojawieniu się człowieka na naszej planecie. Przyjęcie zasady domknięcia przyczynowego wyklucza takie rozumienie genezy życia i człowieka, przy którym konieczny byłby nadzwyczajny akt stwórczy ze strony Boga. Rozwiązaniem tego dylematu może być przyjęcie „hipotezy o niedookreśloności celu stworzenia"46. Jeżeli zamiarem (celem) Boga jest powołanie do istnienia istoty samoświadomej, z którą Bóg mógłby wejść

\footnotetext{
${ }^{46}$ Zob. Grzegorz Bugajak, „Naturalizm nauki a działanie Boga w świecie”, w: Teologia na$u k i$, red. Janusz Mączka, Piotr Urbańczyk (Kraków: Copernicus Center Press, 2015), 165-168.
} 
w szczególną relację (co jest zasadniczą treścią dogmatu o stworzeniu człowieka „na obraz i podobieństwo” Boga), to fizyczny kształt tej istoty jest bez znaczenia. Wystarczy, by materia miała zdolność do samoorganizacji, prowadzącej aż do poziomu świadomości i samoświadomości. Przekonanie, że materia istotnie ma takie własności jest dzisiaj zarówno wnioskiem z badań przyrodniczych, jak i (co ciekawe) jest treścią filozoficznych przekonań materialistycznych, które najczęściej uważa się za wrogie jakiejkolwiek idei Boga. Okazuje się jednak, że nieco bardziej subtelnie rozumienie tej idei sprawia, że znika (definicyjny, zdawałoby się) antagonizm między materializmem a teizmem. Trafne zarzuty wielu ewolucjonistów, wskazujących na przypadkowy charakter procesów ewolucyjnych, co wyklucza możliwość kierowania nimi w taki sposób, by w ich wyniku powstał Homo sapiens tracą swoją moc: istnienie naszego gatunku biologicznego jest rezultatem przypadku; nie powoduje to jednak konieczności zarzucenia przekonań teistycznych, ponieważ tym, czego chciał Bóg, jest Człowiek (jak teologia nazywa samoświadomą istotę, zdolną do szczególnej relacji ze swoim Stwórcą), a nie Homo sapiens.

W kręgach współczesnej myśli chrześcijańskiej są autorzy, którzy idą w kierunku wyżej zarysowanej hipotezy. Kilkanaście lat temu, w znanym czasopiśmie poświęconym relacjom między nauką i religią pojawił się artykuł, rozwijający model stworzenia jako ciągłego procesu. Wychodząc od prostej termodynamiki, przez chemię katalizatorów do najprostszego, samoreprodukującego się i podległego ewolucji organizmu wskazuje on, że nie ma jakichś wyjątkowych rodzajów związków chemicznych, czy źródeł energii koniecznych do tego, żeby taki proto-organizm powstał. Typy związków chemicznych (classes of molecules), które są teraz wszechobecne w życiu na Ziemi mogą być przypadkowymi efektami ubocznymi takiej a nie innej chemii naszej planety ${ }^{47}$. W Polsce w podobnym duchu wypowiada się Tadeusz Pabjan: „Niezwykła aktywność materii i jej zdolność do samoorganizacji prowadzącej do pojawiania się we wszechświecie zupełnie nowych, coraz bardziej zaawansowanych struktur i emergentnych, niesprowadzalnych do siebie poziomów uporządkowania - to wszystko w perspektywie teologicznej jest przejawem aktywnego działania Boga, który za pośrednictwem praw przyrody nieustannie podtrzymuje w istnieniu cały wszechświat i kontynuuje proces jego stwarzania”. Zgodność wizji „przypadkowego Wszechświata” ze światopoglądem chrześcijańskim deklaruje też Marek Słomka: „Ukierunkowanie rozwoju wszechświata na wzrost złożoności nie implikuje idei Boga,

\footnotetext{
${ }^{47}$ Zob. Sherman, Deacon, „Teleology for the Perplexed: How Matter Began to Matter”, 895.
} 
który manipuluje ewolucyjnymi procesami, by doprowadzić je do wykonania precyzyjnie zakodowanego planu. Można natomiast założyć, że spośród wszystkich potencjalnych praw przyrody, Stwórca wybiera taki ich zestaw, który zwiększa prawdopodobieństwo genezy życia oraz świadomości”48. Ten ostatni warunek (konieczność wyboru szczególnego zestawu praw przyrody) można przy tym osłabić, odwołując się na przykład do wizji „doboru naturalnego" wszechświatów, zaproponowanej niegdyś przez Lee Smolina ${ }^{49}$. W takiej perspektywie Bóg niczego szczególnego nie musi „robić”, ponieważ stworzony przezeń świat ze swojej natury realizuje Jego wolę.

\section{PANENTEIZM CHRZEŚCIJAŃSKI}

Odrzucenie szczególnych, nadzwyczajnych Bożych interwencji w świecie spotyka się niekiedy z zarzutem deizmu ${ }^{50}$, który jest koncepcją — jak się słusznie podkreśla - niezgodną z chrześcijaństwem. Niezależnie od tego, że deizm, wbrew potocznym skojarzeniom, jest stanowiskiem bardziej złożonym niż proste twierdzenie o nieangażowaniu się Boga w stworzenie, zarzut ten nie jest trafny przede wszystkim dlatego, że pomija dużo bardziej atrakcyjną alternatywę, jaką jest panenteizm.

Wielu autorów zauważa, że filozoficzno-teologiczna myśl chrześcijańska ma tendencję do pewnego braku równowagi: podkreśla się transcendencję Boga w stosunku do stworzonego świata, zapominając o tym, że przekonanie o Bożej immanencji - stałej i życiodajnej obecności sacrum w sferze profanum - jest równie trwałym elementem chrześcijańskiego dziedzictwa ${ }^{51}$. Wskazanie na panenteizm można potraktować jako próbę przywrócenia tej równowagi i skrótowy sposób łącznego wyrażenia chrześcijańskiej prawdy o Bogu, który jest jednocześnie całkowicie odrębny od świata i całkowicie w nim obecny. Tak rozumiany panenteizm był zawsze elementem myśli chrześcijańskiej. Wyrażał się np. w idei creatio continua: Boga, który stwarza i podtrzymuje świat $\mathrm{w}$ istnieniu — świat nieustannie znajduje się $\mathrm{w}$ sfe-

\footnotetext{
${ }^{48}$ SŁomKa, Działanie Boga w świecie, 220.

${ }^{49}$ Zob. Lee Smolin, Życie Wszechświata. Nowe spojrzenie na kosmologię, thum. Danuta Czyżewska (Warszawa: Amber, 1998).

${ }^{50}$ Zob. np. Patrick GidDY, „Special Divine Action and How to Do Philosophy of Religion”, South African Journal of Philosophy 30, nr 2 (2011): 150; Kazimierz JoDKOwsKI, „Eskapizm teologii i filozofii katolickiej w sprawie «nauka a religia»", Na Poczatku ..., nr 7-8 (2005): 281.

${ }^{51}$ Zob. np. Georg Gasser, "God's Omnipresence in the World: on Possible Meanings of 'en' in Panentheism”, International Journal for Philosophy of Religion 85 (2019): 60.
} 
rze Bożej aktywności ${ }^{52}$, bez której nic by nie mogło aktualnie istnieć. Współcześnie zaś jest istotnym elementem teizmu ewolucyjnego ${ }^{53}$, choć sam ten termin $\mathrm{w}$ analizach teistów ewolucyjnych pojawia się nieczęsto.

Również analizy czysto teologiczne, nawet jeśli unikają nazwy „panenteizm", która - niesłusznie - bywa przeciwstawiana teizmowi chrześcijańskiemu, wskazują na kluczowe elementy tego stanowiska i przeciwstawiają się oddzielaniu Boga od świata. Na przykład, w stosunkowo niedawnym artykule, opublikowanym w katolickim periodyku przez katolickiego księdzateologa czytamy: „Chrześcijanie niekiedy traktowali świat materialny jako coś w rodzaju sceny, na której rozgrywa się dramat zbawienia, która jednak później nie będzie potrzebna. Jest jednak inaczej. Stworzyła go i podtrzymuje w istnieniu miłość Boga. Cały ten proces i wszystkie jego aspekty są dziełem Trójjedynego Boga, i On jest w nim obecny, a wszelkie nowe aspekty są także dziełem Tego, który jest Źródłem wszystkiego i stwarza wszystko [...]. Samoudzielanie się Boga jest rzeczywistością najbardziej immanentną w każdym stworzeniu" ${ }^{54}$. W takiej perspektywie, cały dynamizm świata, wraz z pojawiającymi się $\mathrm{w}$ nim — na przykład na drodze ewolucji - nowościami jest dziełem Boga. Nie w sensie nadzwyczajnych interwencji, które byłyby konieczne dla pojawienia się takich nowości, ani nie w znaczeniu zakodowania $\mathrm{w}$ naturze jakiegoś szczególnego kierunku rozwoju, którego Bóg miałby chcieć, lecz w odniesieniu do Fundamentu i Źródła, w którym „wszystko ma istnienie” (Kol 1,17).

Jeden z najwybitniejszych teologów katolickich XX w., Karl Rahner, uważał, że panenteizm nie tylko jest zgodny z chrześcijaństwem, ale że dopiero jego przyjęcie prowadzi do takiego pojęcia Boga, które jest prawdziwie chrześcijańskie: „Bóg nie jest po prostu kimś, kto jako stwórca stwarza odległy od siebie świat jako coś innego; jest raczej kimś, kto oddaje się temu światu i kto wewnątrz tego świata ma własny los i przeznaczenie. Bóg nie jest tylko dawcą, jest też darem. W panteistycznym rozumieniu istnienia zdanie to może być całkiem oczywiste. W chrześcijańskim rozumieniu Boga, w którym Bóg nie zlewa się ze światem, lecz na całą wieczność pozostaje odeń odrębny, jest to najbardziej przerażające zdanie, jakie w ogóle można o Bogu wypowiedzieć. Jedynie wówczas [jednak], gdy wypowiadamy to zdanie, jedynie wówczas, gdy pojęcie Boga dokonujące radykalnego roz-

\footnotetext{
${ }^{52}$ Zob. np. tamże, 43.

${ }^{53}$ Zob. PABJAN, „Nieinterwencjonistyczny model”, 37-38.

${ }^{54}$ Marek JAGODZIŃSKI, „Trynitarno-komunijna teologia stworzenia”, Roczniki Teologiczne 62, nr 2 (2015): 149.
} 
różnienia pomiędzy Bogiem a światem godzi się ze stwierdzeniem, że Bóg sam jest samym jądrem realności świata i że świat jest rzeczywiście losem i przeznaczeniem samego Boga — jedynie wówczas otrzymujemy pojęcie Boga, które jest rzeczywiście chrześcijańskie" ${ }^{25}$. W perspektywie, w której świat jest „losem i przeznaczeniem” Boga, wszystkie cechy tego świata i wszystkie detale jego ewolucyjnego rozwoju stają się elementem tajemnicy, którą w chrześcijaństwie nazywa się Wcieleniem ${ }^{56}$.

\section{ZAKOŃCZENIE}

Autorom próbującym wykazywać, że nauka i religia, w tym ewolucjonizm i kreacjonizm, nie są ze sobą sprzeczne zarzuca się niekiedy, iż swój cel osiągają kosztem ustępstw $\mathrm{z}$ istotnych elementów tradycji religijnej. Formułowany też bywa postulat, by w imię tej tradycji nie poddawać się w myśleniu religijnym naporowi nauki. Znamienny jest tytuł jednej ze stosunkowo niedawno opublikowanych książek, w której autor protestuje przeciw takim ustępstwom: „Klęcząc przy ołtarzu nauki" ${ }^{57}$. Zarzut ten jest słuszny. Pewne elementy religijnej tradycji muszą zostać współcześnie zakwestionowane. Dziś już tylko na dalekich marginesach myśli religijnej spotkać można na przykład obronę biblijnego datowania historii, przypisującego światu kilka tysięcy lat istnienia. Inne elementy tej tradycji ciągle czekają na to, aż nauka wypełni rolę, jaką przypisywał jej św. Jan Paweł II: uwolnienie religii od błędu i przesądu. Dlatego wspomniany zarzut nie jest trafny: religia może tylko zyskać, jeśli mądrze, bez wylewania dziecka z kąpielą, podda się „naporowi nauki”.

W niniejszym artykule wskazano kilka takich elementów „tradycyjnego” myślenia religijnego, których modyfikacji domaga się współczesna wiedza. Należą do nich rozumienie sposobu obecności Boga w świecie i Jego wpływu na bieg zdarzeń. Czy elementy te zidentyfikowano trafnie jest rze-

\footnotetext{
${ }^{55}$ Karl RAHNER, „The Specific Character of the Christian Concept of God”, w: Theological Investigations, t. 21 (New York: Crossroad Publishing, 1988), 191; cyt. za: PABJAN, „Nieinterwencjonistyczny model działania Boga w świecie przyrody", 40.

${ }^{56}$ Pojęcie „Chrystusa kosmicznego" jest znane w teologii, choć może ciągle nie dość eksplorowane. Por. np. jedną ze znakomitych książek amerykańskiego franciszkanina, Richarda Rohra: The Universal Christ (New York-London: Penguin Random House, 2019).

${ }^{57}$ Robert Bolger, Kneeling at the Altar of Science. The Mistaken Path of Contemporary Religious Scientism (Eugene, OR: Pickwick Publications, 2012).
} 
czą dyskusji. Tym natomiast, co nie ulega kwestii jest potrzeba takiego wysubtelnienia przekonań religijnych, by nie sprowadzały one Boga do roli jednego z trybów — choćby i najważniejszego — w machinie świata.

\section{BIBLIOGRAFIA}

Bergmann, Ralf B. „Does Divine Intervention Violate Laws of Nature?”. Organon F 26, nr 1 (2019): 86-103.

Bielfeldt, Dennis. „Can Western Monotheism Avoid Substance Dualism?”. Zygon 36, nr 1 (2001): 153-177.

Bolger, Robert. Kneeling at the Altar of Science. The Mistaken Path of Contemporary Religious Scientism. Eugene, OR: Pickwick Publications, 2012.

Bradley, James. „Losowość i natura Boga”. Tłum. Ewa Czyżowicz i in. Filozoficzne Aspekty Genezy 11 (2014): 205-240.

BrinK, Gijsbert van den. „In Defence of Dialogue - Yves Gingras, Science and Religion: An Impossible Dialogue" (recenzja). Metascience 28 (2019): 221-228.

Bugajak, Grzegorz. „Naturalizm nauki a działanie Boga w świecie”. W: Teologia nauki, red. Janusz Mączka, Piotr Urbańczyk, 145-172. Kraków: Copernicus Center Press.

BylicA, Piotr. „Naturalistic Theism on General Divine Action within the Framework of the Levels of Analysis Model”. Studia Philosophiae Christianae 52, nr 4 (2016): 7-37.

BylicA, Piotr. „Naturalistic Theism on Special Divine Action within the Framework of the Model of the Levels of Analysis". Studia Philosophiae Christianae 53, nr 1 (2017): 5-33.

DYк, Wiesław. „Celowość przyrody w świetle zasad antropicznych”. Studia Gdańskie 14 (2001): 131-148.

ECKLund, Elaine H., Christopher P. Scheitle. „Scientists”. W: The Warfare between Science and Religion, red. Jeff Hardin, Ronald L. Numbers, Ronald A. Binzley, 279-301. Baltimore, MD: John Hopkins University Press, 2018.

Gasser, Georg. „God's Omnipresence in the World: On Possible Meanings of 'en' in Panentheism”. International Journal for Philosophy of Religion 85 (2019): 43-62.

GidDy, Patrick. „Special Divine Action and How to Do Philosophy of Religion”. South African Journal of Philosophy 30, nr 2 (2011): 143-154.

Gregersen, Niels H. „Special Divine Action and the Quilt of Laws: Why the Distinction between Special and General Divine Action Cannot Be Maintained". W: Scientific Perspectives on Divine Action: Twenty Years of Challenge and Progress, red. Robert John Russell, Nancey Murphy, William R. Stoeger, 179-199. Vaticano: Vatican Observatory Publications; Berkeley, CA: Center for Theology and the Natural Sciences, 2008.

Heller, Michał. „Chrześcijański naturalizm”. Roczniki Filozoficzne 51, nr 3 (2003): 41-58.

JAGODZIŃSKI, Marek. „Trynitarno-komunijna teologia stworzenia”. Roczniki Teologiczne 62, nr 2 (2015): 137-152.

JoDKOwSKI, Kazimierz. „Eskapizm teologii i filozofii katolickiej w sprawie «nauka a religia»”. Na Początku..., nr 7-8 (2005): 261-284. 
JODKOwSKI, Kazimierz. „Kłopoty teistycznego ewolucjonizmu”. W: Kontrowersje wokół początków człowieka, red. Grzegorz Bugajak, Jacek Tomczyk, 209-224. Katowice: Księgarnia św. Jacka, 2007.

JoDKowski, Kazimierz. „Twarde jądro ewolucjonizmu”. Roczniki Filozoficzne 51, nr 3 (2003): $77-117$.

Jones, Kile. „Falsifiability and Traction in Theories of Divine Action”. Zygon 45, nr 3 (2010): 575-589.

Kenny, Anthony. The Metaphysics of Mind. Oxford: OUP, 1992.

KibLINGER, William P. „Evolution and Subjectivity”. Zygon 42, nr 1 (2007): 193-202.

KLoskowski, Kazimierz. „Cel i wyjaśnianie celowościowe ewolucji”. Studia Gdańskie 9 (1993): $257-265$.

Koperski, Jeffrey. Divine Action, Determinism, and the Laws of Nature. London-New York: Routlege, 2020.

LARMER, Robert. „Divine Intervention and the Conservation of Energy: A Reply to Evan Fales”. International Journal for Philosophy of Religion 75, nr 1 (2014): 27-38.

MAJCHEREK, Kamil. „Ockhamowa krytyka teleologii a narodziny nowożytnego rozumienia celowości świata natury". Studia Philosophiae Christianae 53, nr 4 (2017): 49-74.

MajchereK, Kamil. „Tomasz z Akwinu i William Ockham o celowości świata natury”. Rocznik Tomistyczny 5 (2016): 277-289.

Owens, John F. „Creation and End-Directedness”. Sophia 49, nr 4 (2010): 89-498.

PABJAn, Tadeusz. „Nieinterwencjonistyczny model działania Boga w świecie przyrody”. Tarnowskie Studia Teologiczne 35, nr 1 (2016): 33-49.

Plantinga, Alvin. „Divine Action in the World (Synopsis)”. Ratio 19, nr 4 (2006): 495-504.

RAHner, Karl. „The Specific Character of the Christian Concept of God”. W: Theological Investigations, t. 21. New York: Crossroad Publishing, 1988.

Rohr, Richard. The Universal Christ. New York - London: Penguin Random House, 2019.

Saunders, Nicholas. Divine Action and Modern Science. Cambridge: CUP, 2002.

SchönBorn, Christoph. „Odnajdywanie zamysłu w przyrodzie”. Tłum. Piotr Lenartowicz. Filozoficzne Aspekty Genezy 2, nr 3 (2005-2006): 19-22.

Sherman, Jeremy, Terrence W. Deacon. "Teleology for the perplexed: How Matter Began to Matter". Zygon 42, nr 4 (2007): 873-901.

SŁomKa, Marek. Działanie Boga w świecie. Analiza filozoficzna. Lublin: Wydawnictwo KUL, 2018.

Smolin, Lee. Życie Wszechświata. Nowe spojrzenie na kosmologię. Tłum. Danuta Czyżewska. Warszawa: Amber, 1998.

Stoeger, William R. „Describing God's Action in the World in Light of Scientific Knowledge of Reality". W: Chaos and Complexity: Scientific Perspectives on Divine Action, red. Robert J. Russell, Nancey C. Murphy, Arthur R. Peacocke, 239-261. Vaticano: Vatican Observatory Publications; Berkeley, CA: Center for Theology and the Natural Sciences, 1995.

Swinburne, Richard G. „Argument z celowości”. Tłum. Ryszard Mordarski. Analiza i Egzystencja 18 (2012): 59-76.

ŚwIEŻYŃSKI, Adam. Filozofia cudu. W poszukiwaniu adekwatnej koncepcji zdarzenia cudownego. Warszawa: Wydawnictwo UKSW, 2012.

Twardowski, Mirosław. „«Quintavia» św. Tomasza z Akwinu we współczesnej dyskusji filozoficzno-przyrodniczej”. Studia Sandomierskie 24 (2017): 261-274. 
Ulanowicz, Robert E. „A World of Contingencies”. Zygon 48, nr 1 (2013): 77-92.

Wet, Brenda de. „Particular Divine Action: A Challenge to Intellectual Integrity in a Post-Christian Age". South African Journal of Philosophy 27, nr 2 (2008): 93-105.

Wildman, Wesley J. „Evaluating the Teleological Argument for Divine Action”. W: Evolutionary and Molecular Biology. Scientific Perspectives on Divine Action, red. Robert J. Russell, William R. Stoeger, Francisco J. Ayala, 117-150. Vaticano: Vatican Observatory Publications; Berkeley, CA: Center for Theology and the Natural Sciences, 1998.

Wildman, Wesley J. „The Divine Action Project, 1988-2003”. Theology and Science 2, nr 1 (2004): 31-75.

WoJCIECHOwski, Tadeusz. Zarys filozofii przyrody ożywionej, Wydział Teologiczny Uniwersytetu Opolskiego, bmw 1997.

WRÓBLEwSKI, Zbigniew. „O pewnej próbie obrony wyjaśniania teleologicznego”. Roczniki Filozoficzne 60, nr 4 (2012): 339-359.

\section{CZY PROCESY NATURALNE MOGĄ REALIZOWAĆ CELE NADNATURALNE?}

\section{Streszczenie}

Celem artykułu jest poszukiwanie takiej interpretacji obecności i działania Boga w świecie, jaka pozwoliłaby zharmonizować istotne prawdy wiary z naukowym obrazem świata, którego ewolucja jest rządzona przypadkiem i pozbawiona kierunku. Poszukiwanie to jest realizowane w kilku krokach. Odwołując się do różnych koncepcji celowości wskazuje się najpierw, że jeśli można mówić o tym, że świat ma taką cechę, to nie w sensie zmierzania w określonym kierunku (nauki przyrodnicze takiego kierunku nie wykrywają, więc najrozsądniej jest przyjąć, że go nie ma), lecz w sensie celowości wewnętrznej: świat ze swej natury jest skierowany $n a$ Boga.

Współcześnie o Bożej celowości w świecie mówi się często w kategoriach ogólnego lub szczególnego działania Boga (general lub special divine action). Artykuł, podejmując tę kwestię zmierza do wniosku, że odróżnienie aspektu naturalnego od nadnaturalnego w danym zdarzeniu jest przypuszczalnie niemożliwe.

Na jeden z powodów tej niemożliwości wskazuje tzw. zasada domknięcia przyczynowego, dlatego jest ona analizowana w kolejnym punkcie artykułu. Wskazuje się tutaj między innymi na konieczność zrewidowania niektórych klasycznych koncepcji cudu. W odniesieniu zaś do takich przełomowych zdarzeń z dziejów świata, jak powstanie życia czy pojawienie się człowieka, proponuje się hipotezę niedookreśloności celu stworzenia: Bóg może realizować swoje cele w świecie rządzonym przez autentyczny przypadek, jeśli cele te są rozumiane odpowiednio subtelnie. Na przykład, jeśli celem Boga jest pojawienie się w świecie istoty zdolnej do nawiązania z nim świadomego kontaktu (zwanej w teologii Człowiekiem), to istota taka niekoniecznie musiała przyjąć postać przedstawiciela gatunku Homo sapiens.

$\mathrm{Na}$ koniec wskazuje się na panenteizm jako na właściwą, prawdziwie chrześcijańską wizję świata, który jest „losem i przeznaczeniem” samego Boga (Karl Rahner). W tej perspektywie, detale ewolucyjnego rozwoju świata przestają być religijnie istotne, a sama religia uwalnia się ostatecznie - po części pod wpływem współczesnej nauki — „od błędu i przesądu” (Jan Paweł II).

Słowa kluczowe: celowość; działanie Boga w świecie; cud; domknięcie przyczynowe; panenteizm. 


\section{CAN NATURAL PROCESSES REALIZE SUPERNATURAL GOALS?}

\section{S u m m a ry}

The aim of the paper is to seek such an interpretation of the presence and activity of God in nature that could harmonize important truths of faith with scientific understanding of the world, governed in its evolution by chance and devoid of any direction. The search is taken in a few steps. Firstly, classic accounts of teleology are indicated, with the conclusion that the only way of the understanding an idea that the world is purposeful is that in terms of inner teleology: the world is directed not so much by God but towards God.

Contemporary discussions about the possibility of God's aims being realized in nature often concentrate on the notion of general or special divine action. Drawing on some accounts of GDA and SDA the paper supports the view that strict delimitation of what is natural and what divine in a given case is probably impossible.

One of the reasons of this impossibility is captured by the principle of the causal closure of the world. With relation to this principle, a need to revise some classic accounts of the miraculous is pointed to. Particularly, "the miracle of the human" does not need any special divine interventions, any special guidance of the evolutionary processes (which are, in any case, truly random), if one accepts a hypothesis of the underdetermination of the goal of creation: If God's aim is that a special being emerges in nature, able to maintain a conscious relation with its Creator, then such a being (called Human in theology) does not need to be a representative of the species Homo sapiens.

Finally, panentheism is pointed to as a truly Christian view of the world; the world which is "fate and destiny" of God himself (Karl Rahner). In such a perspective, the details of the evolutionary development of the world cease to be relevant for religion, and religion frees itself finally from "error and superstition" (John Paul II).

Keywords: teleology; divine action; miracle; causal closure; panentheism. 